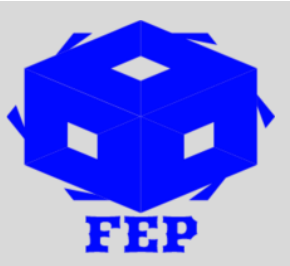

\title{
THE STUDY OF RELATIONSHIP BETWEEN TOBIN'S Q AND US STOCK PERFORMANCE OF SELECTED FIRMS
}

\author{
Papiya Ghosh ${ }^{1}$ \\ ${ }^{1}$ Univeristy of South Florida, USA \\ Brishti Guha ${ }^{2}$ \\ ${ }^{2}$ University of South Florida, USA
}

*Corresponding Author: Papiya Ghosh

Article Received: 19-04-19

Accepted: 27-09-19

Published: 25-10-19

Licensing Details: Author retains the right of this article. The article is distributed under the terms of the

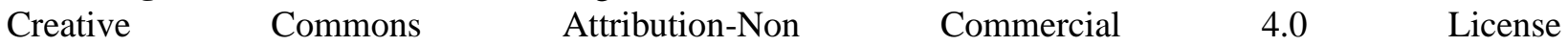
(http://www.creativecommons.org/licences/by-nc/4.0/) which permits non-commercial use, reproduction and distribution of the work without further permission provided the original work is attributed as specified on the Journal open access page.

\section{ABSTRACT}

The objective of study was to test the dynamic effects of changes in Tobin'Q on stock prices of selected 249 US public companies of different industry categories. Panel unit roots tests and cointegration tests are implemented. Next, DOLS and GMM models are estimated. Annual data for the 2004-2012 period are used for the above selected US companies. Panel unit root tests provide somewhat mixed evidence of non-stationarity of both variables. There is clear evidence of cointegration between the above variables. The negative coefficient of the error-correction term shows convergence toward long-run equilibrium, though at slow pace. The estimates also reveal shortrun net positive interactive feedback effects between the variables. Both DOLS and GMM estimates display similar picture of overvaluation of stocks in terms of upward movement in Tobin's Q beyond 0-to-1 range. For most parts of the sample period, the US stock market was in declining mode due to heightening of economic uncertainties during the Great Recession and several years beyond. Tobin's Q should be improved to boost stock prices. This is more of a long-run phenomenon. In the short run, both reinforce each other. The topic is unique and the existing literature on this topic is scant. Relatively new econometric techniques have been applied for estimation using panel data. The results are quite insightful, in our view.

Keywords: Tobin'Q, Stock Performance, Panel Cointegration, Panel ECM, GMM, DOLS 


\section{INTRODUCTION}

The study is based on analysis of influence of changes in Tobin's Q on 249 selected US companies stock prices belonged to the various categories. The time period for analysis was 2004 to 2012. The analysis is based on sophisticated heterogeneous panel cointegration, heterogeneous panel dynamic OLS and dynamic GMM (Generalized Method of Moments) econometric procedures. The Federal Reserve's "Flow of Funds Accounts of United States Z1" is used for obtaining the required data.

Tobin (1969) initially suggested and developed the Q ratio (known as Tobin's Q). For a company, Tobin's $\mathrm{Q}$ is calculated as a ratio of the market value of installed capital to the replacement cost of capital. If a company score low let's say between 0 to 1 , so it indicate that the market value is less than the recorded value of the assets of the company. This suggests that the market undervalues the company with implication for undervaluation of its stock. Whereas, if Tobin $\mathrm{Q}$ is greater than 1 so it implies overvaluation of firm stock. High Tobin's Q encourages organization to make greater capital investment as they are worth more than the price paid. Such measure of stock valuation is the driving factor behind investment decisions in Tobin's Model. It can be said that this ratio plays important role in understanding the financial markets and making investment decisions. It also uses for estimating the consumption and investment based on stock prices.

Usually, stock prices are predicted by dividend yield and price-to-earnings ratio individually as a causal variable. Tobin's $Q$ also significantly helps predict both the above causal variables. The outcome is that often Tobin's Q provide better predictive power for calculating return on stock or investment (\% changes of stock prices). Lang and Stulz (1994) suggests that those companies which are diversified in terms of their products/markets, shows less Tobin's Q due to the lower valuation of the firm assets.

\section{LITERATURE REVIEW}

There is greater interest by financial economists and macroeconomists to better understand price behaviors in the asset markets by testing the different financial variables and macroeconomic variables used for predicting the stock returns (e.g., Cochrane 1991b; Cooper and Priestley, 2005; Lamont, 2000; Lettau and Ludvigson, 2001a; Menzly, Santos and Veronesi, 2004). By understanding how different macroeconomic variables impact return on investment, investors and portfolio managers can make better decisions regarding investment. When it comes to Tobin's Q, it is found to be having strong predictive power for predicting dividend yield ratio and stock price to earning ratio. Tobin's $Q$ thus contains important information in predicting stock returns.

Despite the claim by Black and Scholes (1974) and Miller and Scholes (1982) about no relationship between dividend yield and stock return, other studies empirically supported such relationship. Take example of Blume (1980) who showed a significant positive association between yields and stock returns. Litzenberger and Ramaswamy (1982), and Morgan (1982) support Blume's findings that a positive (yet nonlinear) link between equity returns and dividend yields exists. Kiem (1985) reported that there is positive influence of stock returns on dividend 
yield. Fama and French (1988) showed strong relationship between stock return and dividend yields. Hodrick (1992) showed that stock returns and dividend yield possess strong relationship.. Study of Naranjo, Nimalendran and Ryngaert (1998) also supported such relationship. Some studies showed negative relationship between stock returns and price-to-earnings ratio. For example, Basu (1977) study showed that portfolios of stocks whose price-to-earnings ratios are low, exhibit higher risk-adjusted returns than the portfolios of stocks whose price-to-earnings ratios are high. Peavy and Goodman (1983) also made similar findings. Campbell and Shiller (1988) show an increase in price-to-earnings ratio induces lower growth in equity price. In another study, Harney and Tower (2003) work showed taht Tobin's Q is a better predictor of price-to-earnings ratio when it comes to forecasting stock returns.

Jiang and Lee (2007) find that excess equity risk premiums can be explained by a linear combination of dividends and book-to-market ratio. Sum (2013a) shows that dividend yield and price-to-earnings ratio Granger-cause the movement in stock market returns. In addition, Sum (2013b) shows that Tobin's Q ratio changes forecasts about $67.53 \%$ to $67.78 \%$ of price-toearnings ratio at the two-quarter to eight-quarter horizons. Different research by Sum (2013c) showed that changes in aggregate Tobin's Q forecasts about $6.43 \%$ of the S\&P 500 dividend yield at the 3-quarter horizon and $11.22 \%$ at the 8 -quarter horizon. Other studies also used this ratio for determining the worth of companies in their studies for example, Cho (1998); Lang and Stulz 1994); McConnell and Servaes (1990); Morck et al. (1998).

\section{RESEARCH METHODOLOGY}

The present study used time series observation and cross-sectional based panel data. This type of data is suitable where appropriate number of cross-sectional or longitudinal data is not available. This study decision of using panel data is justified since in this situation we have reasonable number of observations extended over repetitive time period. Furthermore, since the length of the time series is small compared to the number of cross-sections, the effects of autocorrelation are small, if not negligible. Panel data estimation models include the constant coefficient (pooled), the fixed effects and the random effects regression models.

We produce the following econometric model for testing the long=run equilibrium relationship between the specified variables.

yyyy $_{\text {iiiiiiiii }}=\alpha \alpha \alpha \alpha_{\text {iiii }}+\beta \beta \beta \beta_{\text {iiiixxxxx }}$ iiiiiiiii $+\quad \gamma \gamma \gamma \gamma_{\text {iiii }} D D D D_{\text {iiiiiiiii }}+$ eeee $e_{\text {iiiiiiiii }}$

Where, $y=\log$ of stock price (STR) and $x=\log$ of Tobin's Q (TBQ)

$\mathrm{i}=1, \ldots, \mathrm{N}$ and $\mathrm{t}=1, \ldots ., \mathrm{T}$. The panel data set thus has altogether $\mathrm{N}^{*} \mathrm{~T}$ observations.

In model (1), $\alpha \alpha \alpha \alpha_{i i i i}$ shows the possibility of company-specific fixed effects and $\beta \beta \beta \beta_{\text {iiii }}$ allows for heterogeneous cointegrating vectors. $\gamma \gamma \gamma \gamma_{i i i i}$ represents time-dependent common shocks, captured by common-time dummies ( $D D D D_{\text {iiiiiiiii }}$, that might simultaneously affect all the 249 US companies included in this study. Model (1) estimates by following Pedroni $(2000,2001)$ panel Fully Modified Ordinary Least Squares (FMOLS) cointegration technique, which adjusts for the presence of endogeneity and serial correlation in the data. This method is suitable in 
situations where there are possibility of endogenous macroeconomic factors which can cause comovements in the specified variables.

Before estimating model (1), it is required that the order of integration of the variables be determined by using four panel unit root tests. If all variables are found to be I (1), then by using the Pedroni panel cointegration tests $(1999,2000,2001)$ are applied to investigate whether they are co-integrated. The above mentioned tests and techniques are preferred to make sure that no spurious regression phenomenon exists in the estimation of $\beta \beta \beta \beta_{i i i i}$. In order to test for the presence of a unit root in the panel data under study, panel unit root tests as proposed in Im, Peseran and Shin ( 2003); Hadri (1999); Levin, Lin and Chu (2002) and Breitung (2000) are employed. In these tests as suggested, the null hypothesis is based on stationarity of variables. Subsequently, the following panel vector error- correction model in the spirit of (Engle and Granger, 1987) is estimated on the evidence of cointegrating relationship among variables of interest:

$\Delta y y y y i i i i i i i \quad=\alpha \quad+\quad \sum k k k k q q q q=1 \beta \beta \beta \beta \beta \beta \beta \beta \Delta y y y y i i i i i i i i-q q q q+$ $\sum l l l l q q q q=1 \phi \phi \phi \phi \beta \beta \beta \beta \Delta x x x x i i i i i i i i-q q q q+\pi e e e \hat{i} i i i i i i i-1+\mu \mu \mu \mu i i i i i i i i$

To restate, $y=\log$ of stock price (STR) and $x=\log$ of Tobin's Q (TBQ)

If estimated coefficient of the error correction term turns out to be negative, it means there is long run convergence and causal relationship. The estimated $\beta_{\mathrm{i}}$, reveal short-run interactive feedback relationships. The appropriate lag-lengths are determined by the Akaike (1969) information criterion.

Next, Stock and Watson (1993) show that DOLS (Dynamic Ordinary Least Squares) is more favorable, particularly in small samples, compared to a number of alternative estimators of longrun parameters, including those proposed in Engle and Granger (1987), and Phillips and Hansen (1990). Furthermore, Short-run elasticity counterparts are also derived via robust dynamic errorcorrection models (ECMs).

For panel data, the estimating base equation is specified as follows:

$$
\text { Yit }=\alpha 0+\alpha 1 \text { Xit }+ \text { eit }
$$

Four panel unit root tests LLC (Levin, Lin and Chu, 2002),Breitung (2000), IPS (Im, Pesaran and Shin, 2003) and Hadri (1999) are implemented before we conducted panel cointegration.

Based on the Pedroni (2000) guideline, the following model for cointegration between the variables is estimated by DOLS;

$$
\text { Yit }=\alpha \mathrm{i}+\beta \mathrm{iXit}+\gamma \mathrm{tDit}+\mu \mathrm{it}
$$

$\mathrm{Y}_{\mathrm{it}}$ is dependent variable with pooled data and $\mathrm{X}_{\mathrm{it}}$ is explanatory variable with the same.

$\alpha_{\mathrm{i}}$ captures possible company-specific fixed effects and $\beta_{\mathrm{i}}$ allows for heterogeneous cointegrating vector. $\gamma_{\mathrm{t}}$ captures time-dependent common shocks of common time dummies $\left(D_{i t}\right)$.

The DOLS procedure basically involves regressing any $\mathrm{I}(1)$ variables on the other I(1) variables, any $\mathrm{I}(0)$ variables and leads or lags of the first differences of any I(1) variables. 
However, since an investigation of the short-run dynamics are also of interest in the analysis, the panel bi-variate ECM formulation is described as follows in drawing inferences on the long-run and the short-run dynamics:

$$
\Delta \mathrm{Y}_{\mathrm{it}}=\sum_{\mathrm{j}=1}^{\mathrm{k}} \emptyset_{\mathrm{ij}} \Delta \mathrm{y}_{\mathrm{t}-\mathrm{j}}+\sum_{\mathrm{mj}}=0 \mathrm{nj} \Delta \mathrm{xi}-\mathrm{j}+\mathrm{ECit}-1+\epsilon \mathrm{t} \ldots \ldots
$$

Intuitively, when the variables are cointegrated, then in the short term, deviations from this longterm equilibrium will feed back on the changes in the dependent variable in order to force the movement revert towards the long-term equilibrium. If the dependent variable is driven directly by this long-term equilibrium error, then it is responding to this feedback. If not, it is responding only to short-term shocks to the stochastic environment. The significance tests of the 'differenced' explanatory variables give an indication of the 'short-term' effects, whereas the 'long-term' causal relationship is implied through the significance or otherwise of the ' $t$ ' test of the lagged error-correction term, which contains the long-term information since it is derived from the long-term cointegrating relationship(s). The coefficient of the lagged error-correction term, however, is a short term adjustment coefficient and represents the proportion by which the long-term disequilibrium (or imbalance) in the dependent variable is being corrected in each short period. Non-significance or elimination of any of the 'lagged error-correction terms' affects the implied long-term relationship and may be a violation of the underlying theory.

Finally, this study also invokes Generalized Method of Moments (GMM), as developed in Hansen (1982), for robust and efficient estimates. GMM is one of the most widely used econometric tools in finance. A set of moment conditions is used to estimate model parameters by GMM. In general, the number of moment conditions is larger than the number of model parameters. A model misspecification for over-indentifying restrictions can be tested by GMM Jstatistic. GMM does not require strong distributional assumptions for applications in finance.

Because of use of panel data in this study, dynamic GMM panel estimation is preferred over the original GMM estimation. On differencing of the regression equation, unobserved company specific effects and the use of differenced lagged regressors eliminate parameter inconsistency arising from simultaneity bias (Arellano and Bond, 1991). Monte Carlo simulations of the model offer discernible improvements in both efficiency and consistency (Blundell and Bond, 1997).

\section{RESULTS}

Stock prices and Tobin's Q based panel unit root test is provided in the following table. Table1

Panel Unit Root Tests

METHOD

\begin{tabular}{lllll}
\hline Variable (level) & LLC & Breitung & IPS & Hadri \\
& & & & \\
\hline & & & & \\
TBQ & 73.8555 & $-53.0330(0.0000)$ & $(0.0000)$ & $(0.0000)$ \\
& $(0.0000)$ & & & \\
\hline
\end{tabular}




\begin{tabular}{|c|c|c|c|c|}
\hline STR & $\begin{array}{l}5.85355 \\
(0.0000)\end{array}$ & $-0.77535(0.3333)$ & $18.8787(0.000)$ & $\begin{array}{l}0.8783 \\
(0.0000)\end{array}$ \\
\hline VARIABLE (DIFFERENCES) & LLC & Breitung & IPS & Hadri \\
\hline$\Delta(\mathrm{TBQ})$ & $\begin{array}{l}38.1553 \\
(1.0000)\end{array}$ & $-13.8538 *(0.0000)$ & $\begin{array}{l}37.3133 \\
(0.0000)^{*}\end{array}$ & $0.57733 *(0.3818)$ \\
\hline$\Delta(\mathrm{STR})$ & $\begin{array}{l}37.8787 \\
(1.0000)\end{array}$ & $-3.70083 *(0.0003)$ & $35.8773 *(0.0000)$ & $3.01717 *(0.0318)$ \\
\hline
\end{tabular}

Where, TBQ $=\log$ of Tobin's Q; STR $=\log$ of stock price, and total number of observations (NT) 249X9 = 2241 Note: LLC = Levin, Lin, Chu (2002) IPS = Im, Pesaran and Shin (2003). The statistics are asymptotically distributed as standard normal with a left hand side rejection area, except on the Hadri test, which is right sided. *, indicates the rejection of the null hypothesis of nonstationarity (LLC, Breitung, IPS) or staitonarity (Hadri) at the 1 and 5 percent level of significance.

Data from Table 1 suggests that LLC, Breitung and IPS tests show that log of Tobin's Q (TBQ) and $\log$ of stock prices (STR) are nonstationary at 1 percent level of significance. Their counterpart (Hardi) test gave different results at 1 percent level of significance. Furthermore, Brietung test showed evidence of stationary in log of stock prices. In other words, the evidence is mixed for both variables. Subsequently, tests are performed for panel cointegration between TBQ and STR. A battery of seven panel co-integration tests results are reported as follows:

Table 2

Pedroni Panel Co-integration Tests

\begin{tabular}{lll}
\hline \multicolumn{1}{c}{ Test } & Constant trend & Constant + Trend \\
\hline Panel v-Statistic & $-0.84420(0.1700)$ & $-1.26881(+0.8144)$ \\
Panel rho-Statistic & $-126.8848(0.0000)^{*}$ & $-112.2202(0.0000)^{*}$ \\
Panel PP-Statistic & $-46.42822(0.0000)^{*}$ & $-41.42247(0.0000)^{*}$ \\
Panel ADF-Statistic & $-28.82782(0.0000)^{*}$ & $-22 . .4417(0.0000)^{*}$ \\
Group rho-Statistic & $-124.867(0.0000)^{*}$ & $-87.17824(0.0000)^{*}$ \\
Group PP-Statistic & $-44.0887(0.0000)^{*}$ & $-44.80720(0.0000)^{*}$ \\
Group ADF-Statistic & $-24.4888(0.0000) *$ & $-24.27046(0.0000)^{*}$ \\
\hline
\end{tabular}

These tests operated under the no-cointegration as null hypothesis. Six out of seven tests shows that there is cointegrating relationship between STR and TBQ at 1\% significance. Furthermore, the constant trend except panel V statistic also showed anticipatory signs. Thus, mostly evidence suggest that there is cointegration between these two variables based on long-run convergence.

Table 3

Panel Dynamic Least Squares (DOLS) Estimates. Dependent Variable: STR

\begin{tabular}{ccccc}
\hline Variable & Coefficient & Std. Error & t-Statistic & Prob. \\
\hline STR(-1) & 0.89778 & 0.7788 & 4.5553 & 0.0000 \\
TBQ(-1) & -1.98989 & 0.2221 & -5.5494 & 0.0060 \\
\hline
\end{tabular}


Based on the information provided in the above table, it can be inferred that there is short-run negative effects of TBQ changes on STR and one year lag can also be observed in stock prices. These results means that if a company has TBQ of greater than 1, it means overvaluation of stocks since for most parts of the sample period, stock market slid. This would depress investment further pushing stock prices downward.

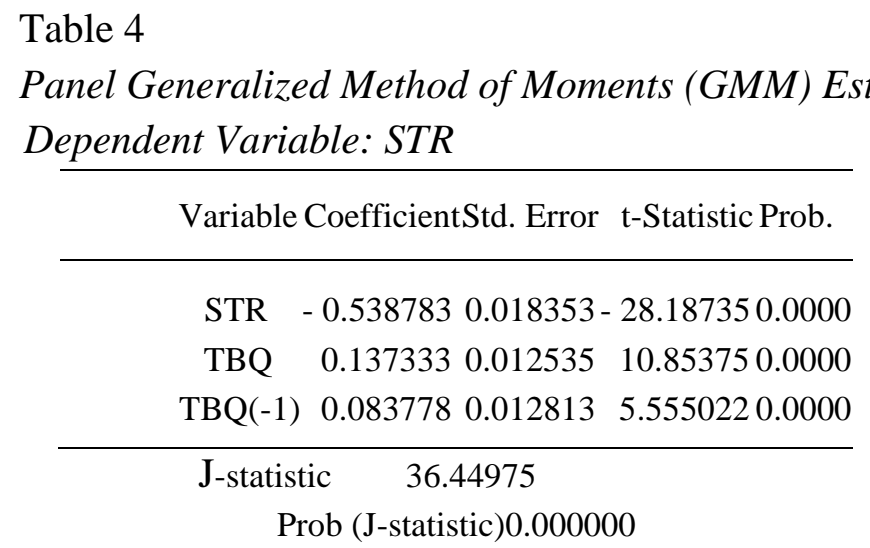

Based on the GMM estimate information provided above, it can be said that there exist short run dynamic effects of preceding STR on current STR. Such net effects are negative implying overvaluation of stocks TBQ being above 1. Moreover, the GMM statistics at 36.44975 confirms that model is not mis-specified. Both GMM and DOLS estimates portray similar pictures with regard to overvaluation of a majority of 249 US company stocks since 2008 during the sample period. However, there are some magnitudinal differences in the coefficients and the associate tvalues.

Finally, the estimates of the VECM are reported as follows:

$$
\begin{aligned}
& \Delta \mathrm{STR}_{\text {iiiiiiiii }}=-0.0074+0.4925 \Delta S \operatorname{SSSSSSSSSS} \mathrm{it}_{\mathrm{it}-1}+0.2805 \Delta \mathrm{STR}_{\mathrm{it}-2}-0.19742 \Delta \mathrm{STR}_{\mathrm{it}-3} \\
& \begin{array}{llll}
(-0.5600) & (14.3745) \quad(8.9978) \quad(-8.8978)
\end{array} \\
& -0.1974 \Delta \mathrm{TBQ}_{\mathrm{it}-1}-0.2446 \Delta \mathrm{TBQ}_{\mathrm{it}-2}+0.0825 \Delta \mathrm{TBQ}_{\mathrm{it}-3} \\
& (-9.7408) \quad(-9.7573) \quad(6.1393) \\
& -0.3938 \mathrm{EC}_{\mathrm{it}-1} \ldots \ldots . .(5)^{\prime} \\
& (-10.6637) \\
& \operatorname{SSSS}^{2}=0.4435, \mathrm{~F}=251.9438
\end{aligned}
$$

Estimated equation (5)' corresponds to equation (5) in the third section. Clearly, the errorcorrection term $\left(\mathrm{EC}_{\mathrm{it}-1}\right)$ has expected negative sign for long-run convergence with high statistical significance in terms of the associated t-value (-10.6637). The short-run interactive net feedback effect of lagged changes in TBQ is negative showing that stock prices decline with TBQ being above one implying overvaluation of stocks. It can be assumed that most of the stocks which we included in the present study shows overvaluation for this period which can be relates with the global financial crisis during the period of 2008. 


\section{CONCLUSION}

Our conclusion is that we found mixed evidence on Tobin's Q and stock prices nonstationarity status. Furthermore, results confirms that both of these variables have good cointegration. The DOLS estimates reveal overvaluation and consequent slide in stock prices due to rising TBQ above unity. The GMM estimates also provide a similar picture in the short run. However, there are some differences in the computed coefficients and their associated tvalues. The estimates of the vector error-correction model show statistically significant convergence toward long-run equilibrium at slow pace and net negative effect implies overvaluation of stocks relating to TBQ.In closing, changes in Tobin's $Q$ have significant effects on stock overvaluation and hence decline in stock prices as an aftermath. Investors should closely monitor changes in TBQ to set and revise investment strategies in light of the aforementioned.

\section{References}

Akaike, H. (1969). Fitting autoregression for prediction. Annals of the Institute of Statistical Mathematics, 21, 243-247.

Arellano, M., \& Bond, S. (1991). Some tests of specification for panel data: Monte Carlo evidence and an application to employment equations. Review of Economic Studies, 58, 277297.

Basu, S. (1977). Investment performance of common stocks in relation to their price-earnings ratios: A test of the efficient market hypothesis. Journal of Finance, 32(3), 663-682.

Black, F., \& Scholes, M. (1974). The effects of dividend yield and dividend policy on common stock prices and returns. Journal of Financial Economics, 1(1), 1-22.

Blume, M. E. (1980). Stock returns and dividend yields: Some more evidences. Review of Economics and Statistics, 62(4), 567-577.

Blundell, R., \& Bond, S. (1997). Initial conditions and moment restrictions in dynamic panel data models. University College London, Discussion Paper in Economics, 97-107.

Breitung, J. (2000). The local power of some unit root tests for panel data, in B. Baltagi (ed.), nonstationary panels, panel cointegration and dynamic panels. Advances in Econometrics, $15,161-178$.

Campbell, J. Y., \& Shiller, R.J. (1998). Valuation ratios and the long-run stock market outlook. Journal of Portfolio Management, 24(2), 11-26.

Cho, M.H. (1998). Ownership structure, investment, and the corporate value: An empirical analysis. Journal of Financial Economics, 47(1), 103-121.

Cochrane (1991b). Production-based asset pricing and the link between stock returns and economic fluctuations. Journal of Finance, 46, 207-234.

Cooper, I., \& Priestley, R. (2005). Stock return predictability in a production economy. Proceedings of the 2005 American Finance Association, Boston, MA.

Engle, R., \& Granger, C.W.J. (1987). Co-integration and error-correction: representation, estimation, and testing. Econometrica, 35, 315-329. 
Fama, E.F., \& French, K. R. (1988). Dividend yields and expected stock returns. Journal of Financial Economics, 22(1), 3-25.

Gujarati, D. (2003). Basic econometrics. Fourth Edition, McGraw- Hill.

Hadri, K. (1999). Testing the null hypothesis of stationarity against the alternative of a unit root in panel data with serially correlated errors. Manuscript, Department of Economics and Accounting, University of Liverpool.

Hansen, L. P. (1982). Large sample properties of generalized method of moments estimators. Econometrica, 50, 1029-1054.

Harney, M., \& Tower, E. (2003). Predicting equity returns using Tobin's Q and price-earnings ratios. Journal of Investing, 12(3), 58-70.

Hodrick, R. J. (1992). Dividend yields and expected stock returns: Alternative procedures for inference and measurement. Review of Financial Studies, 5(3), 357-386.

Im, K. S., Pesaran, M. H., \& Shin, Y. (2003). Testing for unit roots in heterogeneous panels. Journal of Econometrics, 115, 53-74.

Jiang, X., \& Lee, B.S. (2007). Stock returns, dividend yield, and book-to-market ratio. Journal of Banking and Finance, 31(2), 455-475.

Kiem, D. B. (1985). Dividend yields and stock returns: Implications of abnormal January returns. Journal of Financial Economics, 14(3), 473-489.

Lamont, O. (2000). Investment plans and stock returns. Journal of Finance, 55, 2719-2745.

Lang, L.H.P., \& Stulz, R.M. (1994). Tobin's Q, corporate diversification, and firm performance. Journal of Political Economy, 102(6), 1248-1280.

Lettau, M., \& Ludvigson, S. (2001). Consumption, aggregate wealth, and expected stock returns. Journal of Finance, 56, 815-849.

Levin, A., Lin, C.F., \& Chu, C. (2002). Unit root tests in panel data: Asymptotic and finite sample properties. Journal of Econometrics, 108, 1-24.

Litzenberger, R. H., \& Ramaswamy, K. (2012). The effects of dividends on common stock prices tax effects or information effects?. Journal of Finance, 37(2), 429-443.

McConnell, J.J., \& H. Servaes. (1990). Additional evidence on equity ownership and corporate value. Journal of Financial economics, 27(2), 595-612.

Menzly, L., Santos, T., \& Veronesi, P. (2004). Understanding predictability. Journal of Political Economy, 112, 1-47.

Miller, M. H., \&Scholes, M. S. (1982). Dividends and taxes: Some empirical evidence. Journal of Political Economy, 118-1141.

Morck, R., Shleifer, A., \&Vishny, R.W. (1988). Management ownership and market valuation: An empirical analysis. Journal of Financial Economics, 20, 293-315.

Morgan, I.G. (1982). Dividends and capital asset prices. Journal of Finance, 37(4), 1071-1086.

Naranjo. A., Nimalendran, M., \& Ryngaert, M. (1998). Stock returns, dividend yields, and taxes. Journal of Finance, 53(6), 2029-2057.

Peavy III, J. W., \& Goodman, D. A. (1983). The significance of P/Es for portfolio returns. Journal of Portfolio Management, 9(2), 43-47. 
Pedroni, P. (1999). Critical values of cointegration tests in heterogeneous panels with multiple regressors. Oxford Bulletin of Economics and Statistics, 61, 653-670.

Pedroni, P. (2000). Fully modified OLS for heterogeneous co-integrated panels, in Baltagi, B. and C. D. Kao (Eds;), advances in econometrics, nonstationary panels, panel cointegration and dynamic panels. New York: Elsever Science, 93-130.

Pedroni, P. (2001). Purchasing power parity tests in cointegrated panels. Review of Economics and Statistics, 83, 727-731.

Phillips, P.C.B., \& Hansen, B.E. (1990). Statistical inference in instrumental variables regression with I(1) processes. Review of Economic Studies, 57, 99-125.

Stock, J.H., \& Watson, M. (1993). A simple estimator of cointegrating vectors in higher order integrated systems. Econometrica, 61, 783-820.

Sum, V. (2013). The orthogonal response of stock returns to dividend yield and price-toearnings innovations. Accounting and Finance Research, 2(1), 47-53.

Sum, V. (2013). Dynamic effect of Tobin's Q on price-to-earnings ratio. Managerial Finance, 40(6), 634-643.

Sum, V. (2013c). Stock market dividend yield and Tobin's Q. Working Paper, University of Maryland.

Tobin, J. (1969). A general equilibrium approach to monetary theory. Journal of Money, Credit and Banking, 1(1): 15-29. 